Article

\title{
A Spatial Fuzzy Multicriteria Analysis of Accessibility: A Case Study in Brazil
}

\author{
Josiane Palma Lima ${ }^{1, *(\mathbb{C}}$, Juliana da Camara Abitante ${ }^{2}{ }^{(}$, Nívea Adriana Dias Pons ${ }^{3}(\mathbb{C}$ and \\ Clara Moreira Senne ${ }^{4}$ (D) \\ 1 Industrial Engineering and Management Institute, Federal University of Itajuba, \\ Itajubá CEP 37500-903, Brazil \\ 2 Master's Program in Technologies and Society Development, Federal University of Itajuba, \\ Itajubá CEP 37500-903, Brazil; jcabitante@gmail.com \\ 3 Natural Resources Institute, Federal University of Itajuba, Itajubá CEP 37500-903, Brazil; \\ niveadpons@gmail.com \\ 4 Ph.D. Program in Industrial Engineering, Federal University of Itajuba, Itajubá CEP 37500-903, Brazil; \\ clarasenne@gmail.com \\ * Correspondence: jplima@unifei.edu.br
}

Received: 15 April 2019; Accepted: 18 June 2019; Published: 20 June 2019

check for updates

\begin{abstract}
Accessibility is a well-established concept in sustainable transportation literature; however, it is often measured through accessibility models that are still being developed. This article presents an accessibility evaluation model that applies multiple attributes, fuzzy functions, and spatial analysis tools. The model determines indices that reflect an average level of attractiveness for each potential destination (deemed a location of interest-LI). Each destination has different weights based on its degree of importance. Moreover, the model was developed in two phases: The first considered cost-distance metrics, and the second incorporated ground friction factors. The application of the model provides great contribution to the region under study (Campos do Jordão, a city located in a mountainous region of the state of São Paulo), thus presenting some implications for sustainable urban planning and mobility policies, especially in segregated areas with mixed inhabitant populations between tourists and local residents. The results have shown that special attention should be paid to planning new school facilities and city transportation systems. Most of these services are currently concentrated in the city's downtown area, making access to urban facilities inefficient and unfair. Using the results in urban projects, the allocation of future urban facilities or the reallocation of current urban facilities contributes to reduced impacts on urban mobility caused by individual motorized transportation in daily activities.
\end{abstract}

Keywords: accessibility; sustainable urban mobility; urban facilities; spatial multicriteria analysis; fuzzy function; sustainable development

\section{Introduction}

Providing locations with suitable accessibility has become a growing challenge and concern for urban and regional planners. Accessibility is a well-established concept in transportation literature; however, it is often measured through accessibility models that are still being developed. The concept of access or accessibility can be defined as the relationship between the daily activity in a territory and the transportation system serving said area, under the assumption that spatial interaction or reachability decreases with the increase of travel distance and time needed to reach an opportunity $[1,2]$. Mobility in cities should provide individuals with access to public services and social functions. Accessibility, in turn, contributes to the mobility of the individual throughout the city, generating and 
increasing quality of life as well as sustainable development, while also influencing the relationship of the spatial position of the dwelling in relation to the opportunities. The ability, quantity, and diversity of possibilities to access activities, services, places, information, and other people is an essential issue in the quality of urban space, serving as a counterpoint to the fragmentation and dispersion found in many contemporary cities [3].

The value of accessibility as an integrative device, particularly in its ability to establish a connection between transportation and land use, has recently gained ground in institutions that can effectively wield it as a planning tool [4,5]. Murawskia and Church [6] introduced a model that can be used to maximize access to health facilities by making selected improvements to the road system. Paez et al. [7] illustrated how positive and normative accessibility indicators can be used in tandem, testing the extent to which the behavioral experiences of individuals conform to an existing policy or suggested norm. The pedestrian scale accessibility was studied by Foti and Waddell [8] through a hierarchical graph of tradeoffs between modes and integration of micro-scale land-use data to measure the full range of alternative destinations in the city. Campbell et al. [9] showed that place-based accessibility is comparatively better in contour and gravity measures. However, the wealthiest areas have very low levels of place-based accessibility for all modes, while poorer areas have comparatively better walking access to health facilities. Chou et al. [10] presented a fuzzy multicriteria decision model for selecting a location for a tourist hotel, analyzing location factors and making a dispassionate and objective location selection. This allows managers and decision-makers to sharpen their competitive edge. The proposed methodology by Bocarejo and Oviedo [11] can be used as an additional element in decision-making processes regarding where and how to respond to transport disadvantages in cities that experience transport-related inequalities.

Sun et al. [12] commented that compact cities, mixed-use, and polycentric spatial development may ease the burden of commuting. Lynch [3] initially introduced the concept of "Good City Form," proposing a normative theory that relates the value of a city to its spatial characteristics. In this theory, access (performance measure) is the extent to which goods, services, places, and information are accessible with minimum time, distance, and effort. Most traditional approaches to accessibility models use distance and travel time (the trip cost) between the origin and destination in daily activities [13-16]. In addition to distance and travel time (the trip cost), other indicators have been incorporated in these models, such as number of trips (or frequency), number of points of origin, and destination (attractiveness/opportunities) [2,17].

Urban planning should be aligned with the needs of the population $[18,19]$, and the decision maker must understand the urban complexity without disregarding the needs of those who live in this environment. The dynamics of cities and their evolution over time influence how people perform their daily activities. In this context, accessibility must be addressed to consider the following elements: people (human behavior), production (economics), places (land use), and plexus (the network) [20].

During the past two decades, considerable progress has been made in academic literature on accessibility [21,22]. The topic has been an important element in studies that address (i) transportation/land-use interactions [23-27], (ii) travel demand [28-31], (iii) relation of transportation projects with equity and territorial development [32,33], and (iv) location problems for urban facilities [34-36]. With the development of information geoprocessing technologies, models have become more robust, allowing for spatial analysis and the introduction of new assessment tools, such as socioeconomic variables and friction factors, among others $[17,37,38]$. Spatial analysis is a quantitative study of phenomena that may be located in a geographic area [39-42]. The GIS-based studies combining fuzzy models can be found in papers for accessibility including landfill sitings [43] or land-use suitability analyses [44]. The environment is the focus of studies that use GIS for land suitability analyses for different crops [45], forest conservation planning [46], and outranking land-use suitability assessment [47]. Spatial analyses contribute to the analysis of accessibility when considering a set of interdisciplinary factors [8,48-52], such as the case of Agbenyo et al. [53] that used GIS to model community accessibility to health facilities. 
Levinson et al. [20] defined accessibility as the mathematical product of the number and quality of destinations that can be reached and as the general cost (combining time, money, and other factors) of reaching them. More specifically, a cumulative opportunity-to-accessibility measure evaluates the number of destinations that can be reached in a given time threshold. Nontraditional approaches in this study are related to the use of the Fuzzy Multicriteria Analysis Method integrated to a spatial analysis to determinate the accessibility index of a given region in relation to a destination (attraction) [54-56], and each destination has a different importance. In this approach, accessibility was evaluated according to a purpose, opportunity, or location of interest (LI). It is based on the cost-distance effect between the origin and LI. Locations of interest can be public or private facilities such as schools, health centers, and others services. In the model, LI are criteria that contribute to the accessibility final index. The importance of this evaluation is in incorporating attributes of each region, including different points of view about the evaluated location.

In order to obtain an accessibility index, one must determine the degree of importance of the criteria by assigning a weight to the LI. A meeting was held with the participation of experts in urban mobility, comprising postgraduate students and professors, to obtain a consensus about the degree of importance and weights of the locations of interest and to reach this goal. Therefore, different points of view were combined through a brainstorming session.

GIS-based Multicriteria Analysis can be thought of as a collection of methods and tools for transforming and combining spatial data and preferences (value judgments) to obtain information for decision-making [39,41,57-59]. When other tools were combined, such as fuzzy set, the model became even more robust [60-62]. In light of the complexity of the decision-making problem, different models have been proposed for rural and urban environment accessibility $[17,26,48,55]$. Some models have used Multicriteria Decision Analysis (MCDA) [34,63,64], which are methods widely used for complex problems involving the choice, prioritization, or selection of alternatives in numerous applications which aid in decision-making $[41,65,66]$.

Within the context of multicriteria decision-making in transportation, Banai [67] developed a model to assess a Light Rail Transit (LRT) corridor and route alternatives using Analytic Hierarchy Process (AHP) [68] with a set of criteria for policy objectives. Banai [69] applied the Analytic Network Process (ANP) [70] to the light rail route selection with station area land use and property value among the multiple criteria. Taleai et al. [34] introduced an Integrated Spatial Equity Evaluation (ISEE) framework based on spatial multicriteria analysis to evaluate equitable access to several basic services used mostly by children. Hawas et al. [64] evaluated transit accessibility using three indicators: coverage (spread of service), supply (effectiveness measure), and route diversity. In turn, the association between GIS and Multicriteria Methods has shown itself to be an effective approach for a wide variety of other decision-making problems, such as tourism [71,72], waste management [73,74], and agriculture [75,76]. Multicriteria evaluation models allow for the calculation of accessibility indices in a given region in relation to the location (destinations or attraction) considered. Table 1 presents a summary of the literature that support modeling and analysis in this work.

Thus, this paper aims to present an accessibility evaluation model, which aggregates multiple attributes, fuzzy function, and spatial analysis tools. The model determines indices that reflect an average level of attractiveness for each potential destination (location of interest-LI) and weighs each destination by its degree of importance. The territorial accessibility index was determined in two stages: The first considered distance-cost metrics (distance by road), and the second incorporated friction factors (type of pavement and declivity).

In order to apply the proposed model, a case study was carried out in Campos do Jordão in the state of Sao Paulo, Brazil. The strategic methodology was to investigate the phenomenon of territorial accessibility using a Geographic Information System (GIS-ArcGIS). Campos do Jordão is a medium-sized Brazilian city with peculiar characteristics, such as its highly sloped topography and mountain-based tourism. The proposed accessibility evaluation model proved to be an efficient and flexible tool, making it possible to create different scenarios to represent reality and distinct opinions. 
The incorporation of friction factors enabled the generation of maps that represented accessibility conditions in a more accurate way. The result of the application of the method, when compared to on-site observations, demonstrated coherence with the city's actual situation.

Table 1. Summary of literature contributions.

\begin{tabular}{cc}
\hline Contribution & Reference \\
\hline $\begin{array}{c}\text { Accessibility addressed transportation planning and } \\
\text { transport/land-use interactions }\end{array}$ & $\begin{array}{c}\text { Geurs \& Wee [4], Litman [5], Páez et al. [7], Geurs [21], } \\
\text { Wang et al. [22] Wilson [23], Badoe \& Miller [24], } \\
\text { Shaw \& Xin [25], Renne [26], Mayaud et al. [27] }\end{array}$ \\
$\begin{array}{c}\text { Accessibility addressed the relation of transportation } \\
\text { projects with equity and sustainable } \\
\text { territorial development }\end{array}$ & $\begin{array}{c}\text { Bocarejo \& Oviedo [11], Niehausa et al. [32], } \\
\text { Beiler \& Mohammed [33] }\end{array}$ \\
$\begin{array}{c}\text { Accessibility addressed location problems for } \\
\text { urban facilities }\end{array}$ & Campbell et al. [9], Taleai et al. [34], Zhang et al. [35], \\
Li \& Tong [37],
\end{tabular}

\section{Materials and Methods}

The accessibility index has been calculated through spatial analysis integrated with a multicriteria evaluation method $[20,55,56,77,78]$. New contributions are presented each time they are applied, either by the unique nature of each area or by the way the decision criteria are incorporated and analyzed in the GIS [57-59,79].

Accessibility was evaluated according to purpose (locations of interest, LI), as they are called in this paper). The LI are criteria that have different degrees of importance in the final value of the accessibility index. For example, the location of a school might be considered more important than a supermarket and less important than a hospital. The evaluation incorporates attributes for each region, including different points of view about the evaluated destination. It is based on the distance-cost effect between the origin and LI. This technique has been used in several other studies, proving to be efficient for accessibility approaches $[20,56,77]$. In this study, different friction factors and decision criteria were incorporated into the technique, and when it was associated to a case of unique nature, it brought a new contribution to the study of accessibility.

Observations and interviews were the means used for data collection and enabled the elaboration of the accessibility evaluation model and the scenario studies. All the information was processed using GIS (software package ArcGIS 10.4), through which spatial analyses were carried out and maps were produced for these accessibility indices.

Two phases of analysis were conducted, as seen in Figure 1. In Phase I, an accessibility index map was developed for each LI in the vector model, where each node of the roadway network (generated based on vertices that represent the road network) possesses an accessibility factor in relation to the LI. The cost-distance metrics were calculated considering the shortest distances between the transportation network nodes and the locations of interest. 


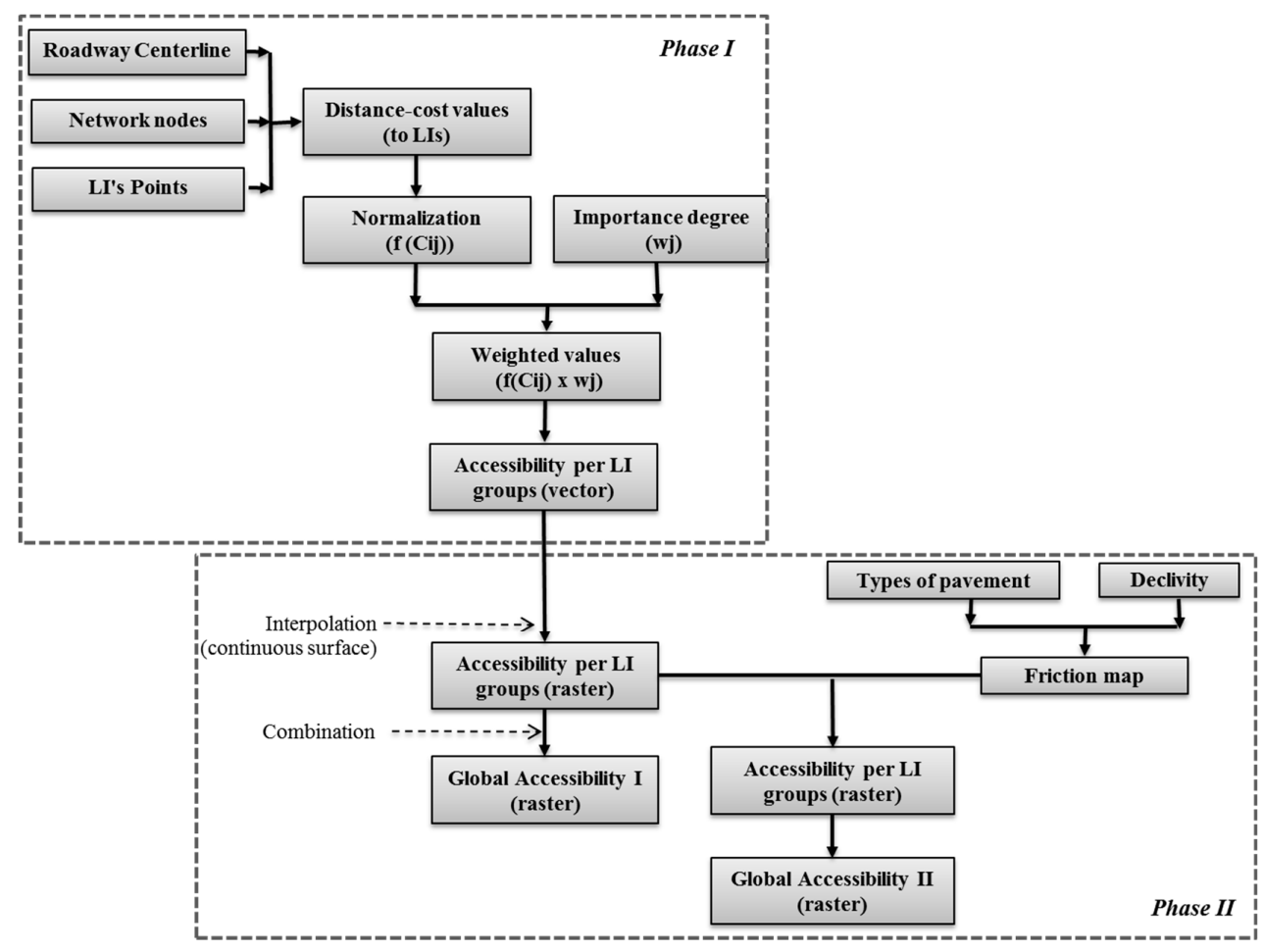

Figure 1. Analysis in a GIS environment.

Accessibility is determined by an index $A i$ for location $i$ [77], where $c_{i j}$ is the cost-distance value between origin $i$ and location of interest $j ; f\left(c_{i j}\right)$ is the normalization of cost-distance using fuzzy function, and $w_{j}$ is the degree of importance of locations of interest $j$. Multiple destinations (LI) under analysis can be complementary or equivalent and should be grouped by affinity or interest, enabling the generation of different scenarios. These scenarios represent indices for accessibility by LI groups $\left(A_{i}^{g}\right)$ with the number of locations of interest in group $n_{g}$, calculated by Equation (1). When the indices are combined (Equation (2)), they generate a global accessibility index $\left(A_{i}\right)$.

$$
\begin{gathered}
A_{i}^{g}=\sum_{j}^{n_{g}} f\left(c_{i j}\right) w_{j}^{g} \\
A_{i}=\sum_{g} A_{i}^{g} \cdot w_{g}
\end{gathered}
$$

Equations (1) and (2) correspond to the weighted linear combination (WLC), which allows for the calculation of the accessibility index for destination groups (LI) and the global index with the tradeoffs. In the literature, there is a set of procedures for defining weights, such as the Analytic Hierarchy Process (AHP) $[68,80]$, in that the importance of the criteria is determined through pairwise comparison judgments. For example, Machado and Lima [63] used AHP to evaluate walking accessibility related to individuals with reduced mobility; Rodrigues et al. [17] and Sakamoto and Lima [56] determined the decision criteria weights using AHP to evaluate the respective territorial accessibility. Rank sum and rank reciprocal [81] are based on ordering criteria. The weights are defined by specialists or by a population who provide information based on individual experiences when considering the region's characteristics. Banai and Wakolbinger [82] used the ANP applications in a non-survey empirical approach, deriving the weights that signify country influence by using a combination of qualitative and quantitative data from a variety of sources. These are different ways of determining criteria importance.

The brainstorming method [83] was used with urban mobility specialists to verify the group's overall opinion regarding the relevance of urban facilities in the accessibility assessment process. 
During brainstorming, the stakeholders were asked to consider the different daily needs of each person, inhabitant, and tourist. Advertising executive Alex Faickney Osborn began developing methods for creative problem solving in 1939. The term "brainstorming" was disseminated by him in 1953 in his book Applied Imagination [84] and basically constitutes a way to come up with many ideas that one would not be able to generate alone through the leveraging of group or collective thinking by engaging with one another and listening and building on each other's ideas. Having in mind the generation of ideas is a critical part of the innovation process [85], and many organizations consider brainstorming to be an effective technique for generating a large number of creative ideas and for increasing organizational competitiveness [86,87]. Thus, it is a technique for solving problems in groups in which stakeholders debate alternatives with the overarching goal of decision-making [88].

Brainstorming served as an appropriate method because it allowed stakeholders to discuss alternatives to achieve the overarching goal of accessibility, considering the judgments and perspectives of each person. Afterwards, many discussions were held about the importance of the different LI considering accessibility criteria during the assessment until a consensus was obtained about the weight that should be attributed to each LI (see Section 3.1). Through brainstorming methods, we also analyzed the maximum distances from households to urban facilities in order to facilitate the accessibility of daily activities of inhabitants from the study city.

In Phase II, the spatial analyses were executed, superimposing the accessibility index and friction map and generating new accessibility results. In this phase, the type of urban road pavement and territory slope (declivity) were adopted as main contributing factors for friction generation. It is important to highlight here that the model allows for the analysis of isolated scenarios for each LI, for example, territorial accessibility for schools in relation to health centers and even the combination of these indexes to generate a global territorial accessibility result.

In Brazil, typically only governmental agencies in large cities have ready and retrievable data sources. An origin-destination survey would be the most appropriate way for data collection and analysis, such as the availability and ease of use of each transportation mode. The model allows using other factors. The most widely used transportation mode, including transport infrastructure, could also be considered an impedance factor or the ease of reaching the destination (LI). For example, if there was reliable information about the sidewalks, we could include them in the analysis. That would improve the results with information (criteria) on pedestrian safety and comfort.

In order to combine all the cost-distance values with the weights for each LI, one must normalize them for the same scale of comparable values. This process is done through fuzzy functions, with the possibility of using multiple types of functions which can be utilized to orient the variation of the minimum and maximum values for the specific criterion, such as Sigmoidal, J-Shaped, Linear, and Complex (for more information about normalization procedures using fuzzy functions, see Rodrigues et al. [17]). The fuzzification process aimed to normalize the cost-distance ratios in a continuous variation between 0.00 and 1.00, using linear and sigmoidal functions (Figure 2a,b, respectively) according to each type of LI. The development details of the two phases and each part are explained in the next section.

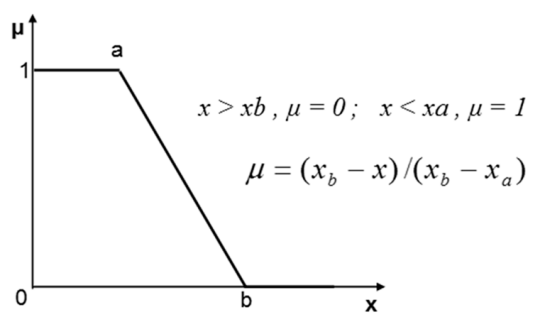

(a)

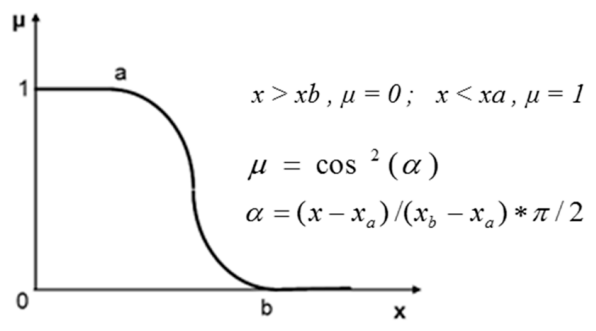

(b)

Figure 2. Fuzzy functions for normalizing distance-cost values. (a) Decreasing linear function. (b) Decreasing sigmoidal function. 


\section{Results}

With the goal of applying the proposed model, a case study was conducted in Campos do Jordão in the state of São Paulo, Brazil. The strategic methodology was used to investigate the phenomenon of territorial accessibility. The city under study has an area of $290.05 \mathrm{~km}^{2}$, with 47,789 inhabitants and a population density of 164.49 inhabitants $/ \mathrm{km}^{2}$ [89].

For the multicriteria accessibility assessment, the LIs are based on urban facilities, that is, the purposes of the daily trip (commute). For the multicriteria evaluation of the territorial accessibility of Campos do Jordão, the locations of interest were defined based on the urban functionalities that represent reasons for traveling for the inhabitants of the city. However, as no origin-destination research had ever been conducted in the municipality, the inhabitants' trips to work were not considered. It was not possible to define the transportation mode for each LI. The absence of these data was a limiting factor, and the study was based on the availability and readiness of information. The primary data maps in Figure 3 show some key characteristics of the region under study.

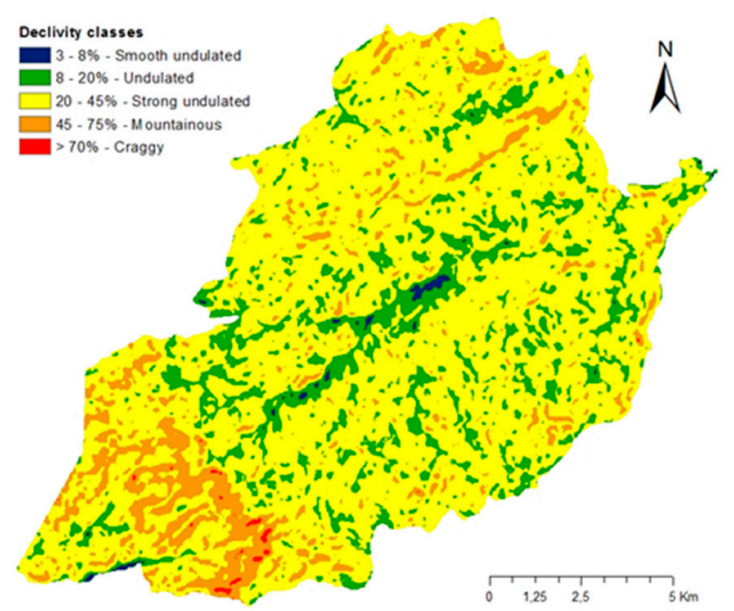

(a)

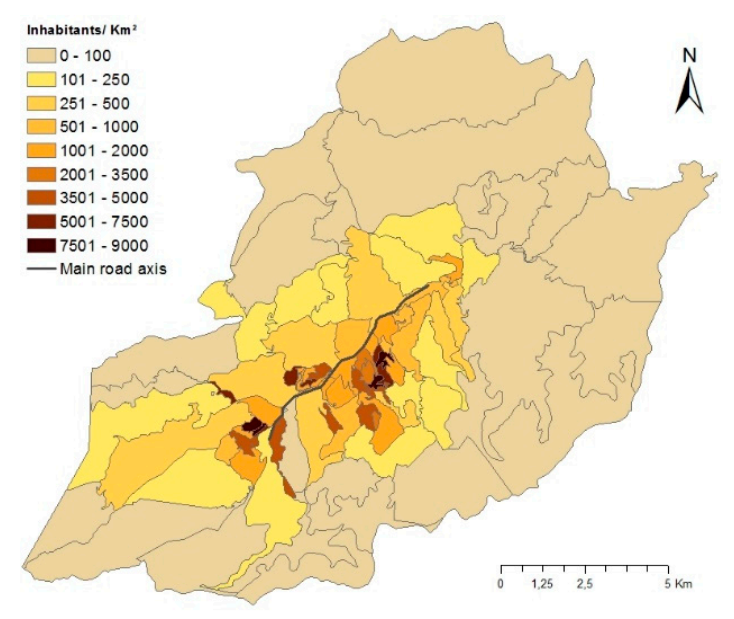

(c)

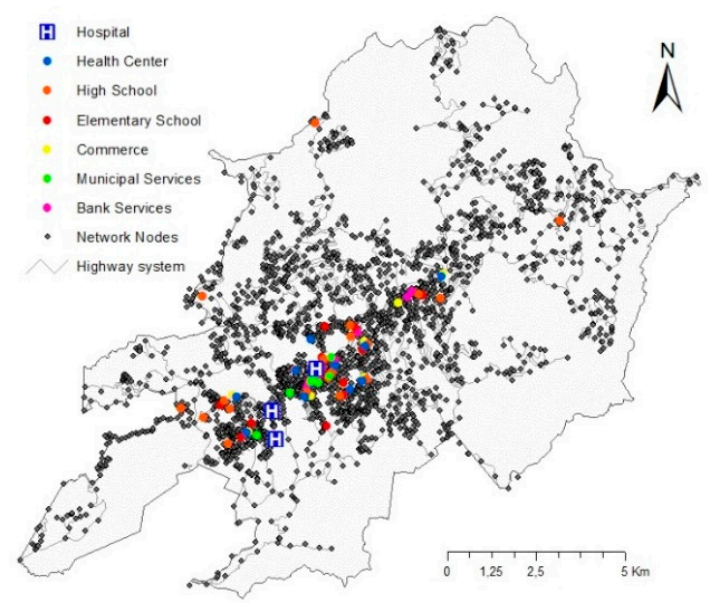

(b)

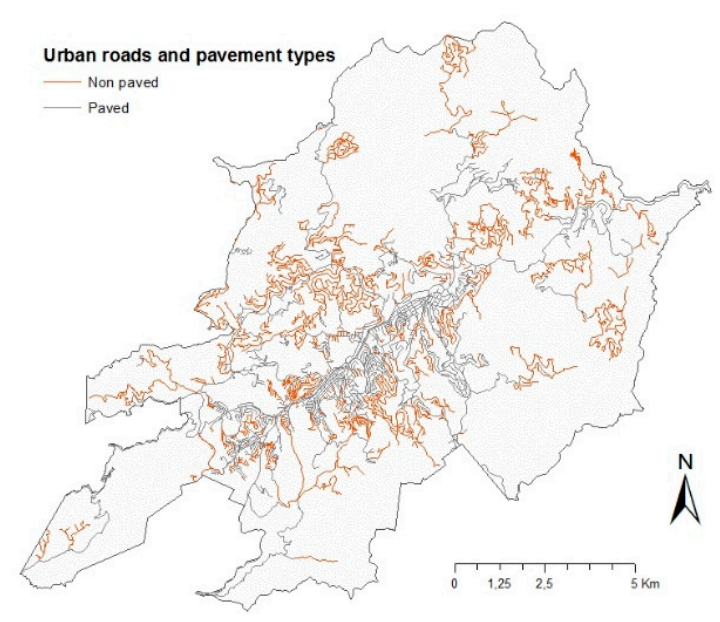

(d)

Figure 3. Primary data: (a) Declivity; (b) locals of interest and network nodes; (c) demographic density and thoroughfare; and (d) urban roads and types of pavement.

Initially, a georeferenced database was chosen, using declivity (Figure 3a); primary roadway data (layers, with a topological arch), network nodes (layer points, generated from vertices lines in a roadway network system), and position of LI (again, nodes on the layers, defined by urban facilities) 
(Figure 3b); demographic density (raster classification, Figure 3c); and pavement type for the roadway network (Figure 3d). It is important to highlight that all the roadway nodes are considered as origins in the accessibility analysis while all LI are determined as destinations. By classifying the declivity in Figure $3 a$, it can be determined that the region has a very hilly landscape with slopes ranging from $20 \%$ to $45 \%$. The areas with the greatest slopes are in the southeastern portion of the municipality; the flattest portions are around the bed of Capivari Creek, which plays an important role in the city's hydro-system.

Urban facilities located in the city were divided into 3 LI groups: (i) "Education facilities", with subgroupings for "Early Education" and "High School"; (ii) "Health Facilities", with subgroups for "Healthcare centers" and "Hospitals"; (iii) "Goods and Service Facilities", with subgroups for "Commerce" and "Banking Services"; and "Public Services", with a total of $104 \mathrm{LI}$, as presented in Table 2. The largest LI concentrations (Figure 3b) are located in areas with the largest geographic density (Figure 3c), which run along the municipality's main road axis. However, there are other residential neighborhoods, which are farther from the main road axis and do not have schools and health centers. The area's great declivity and the unpaved roads exacerbate the access problem.

The roadway system (Figure 3d) covers an extension of $6222 \mathrm{~km}$ on urban thoroughfares; $48 \%$ is paved, while $52 \%$ remains unpaved. It was not possible to analyze which roadways have sidewalks. Paved roadways have a higher rate of public transportation, which enables quicker transportation than on unpaved roads for both automobiles and bicycles. This, in turn, provides a greater level of accessibility.

\subsection{Importance of Locations of Interests and Distance-Cost Definition}

The evaluation method for accessibility requires determining the level of importance for each LI. A group of urban mobility specialists comprising postgraduate students and professors and totaling nine individuals participated in a brainstorming session to reach a consensus.

Table 2. Locations of interest (LI) by group and quantity.

\begin{tabular}{|c|c|c|}
\hline Group & Location of Interest & Number of Locations \\
\hline \multirow{2}{*}{ 1-Education } & Elementary School & 25 \\
\hline & High School & 22 \\
\hline \multirow{2}{*}{ 2-Health Services } & Health Centers & 11 \\
\hline & Hospitals & 3 \\
\hline \multirow{3}{*}{ 3-Services and Goods } & Commerce & 10 \\
\hline & Bank Services & 15 \\
\hline & Municipal Services & 18 \\
\hline \multicolumn{2}{|c|}{ Total } & 104 \\
\hline
\end{tabular}

Each participant was to order the criteria and to define them in a descending order of importance. Based on this ranking, a total starting score was defined. A total sum of 1.0 was possible; the points were distributed between the LI, observing the order of importance. Rankings were defined according to the frequency in which the inhabitants travel to the facilities and the number of people who use or operate the locations as an opportunity (destination). The brainstorming method proved to be a good tool for this purpose, setting education in first with the greatest weight, followed by health and, finally, services and goods, as can be seen in Table 3.

Among the LI under study, the subgroup identified by the team as having the greatest importance were elementary schools. This choice was based on the fact that this facility is used by a portion of the population that does not have complete autonomy of mobility and thus must be located near the individual's place of residence. 
This assessment was unanimous among the team and justified in that education is fundamental for sustainable development. That is, public management should prioritize the location of elementary education facilities in order to increase accessibility for the city's inhabitants.

The subgroup "Hospitals" scored lower in importance on the technical evaluation, given that traveling to a hospital happens less frequently. Thus, distance is not a fundamental question related to its location because residents do not access this location on a daily basis.

Table 3. Weights of groups and locals of interest.

\begin{tabular}{cccc}
\hline Group & Weight & $\begin{array}{c}\text { Location of } \\
\text { Interest }\end{array}$ & Weight \\
\hline \multirow{2}{*}{ Education } & \multirow{2}{*}{0.40} & Elementary School & 0.60 \\
& \multirow{2}{*}{0.35} & High School & 0.40 \\
\hline \multirow{2}{*}{ Health } & & Health Centers & 0.70 \\
& \multirow{2}{*}{0.25} & Hospitals & 0.30 \\
\hline \multirow{2}{*}{ Services and Goods } & & Commerce & 0.40 \\
& & Bank Services & 0.30 \\
& & Municipal Services & 0.30 \\
\hline
\end{tabular}

The specialists also participated in defining maximum distance values. These distances represent the absolute limits from a determined residency to an LI; accessibility will be considered null (value of 0 ) if the value is above the maximum distance value. The averages of the maximum values are presented in Table 4.

These distances are control points of each fuzzy function used during the normalization of distances between network nodes and LI. The minimum distance adopted was $200 \mathrm{~m}$; any value above this is considered to have maximum accessibility (value of 1 ). This distance represents the average length of a city block. Considering an average speed of $4.5 \mathrm{~km} / \mathrm{h}$ [90], a distance of $200 \mathrm{~m}$ is covered in an average of two-and-a-half minutes.

Table 4. Maximum distances.

\begin{tabular}{cc}
\hline LI & $\mathbf{D}_{\max }$ (Meters) \\
\hline Elementary School & 960.00 \\
High School & 1400.00 \\
Health Centers & 1600.00 \\
Hospitals & 7500.00 \\
Commerce & 1660.00 \\
Bank Services & 4300.00 \\
Municipal Services & 5000.00 \\
\hline
\end{tabular}

For hospitals, banking, and public services, linear decreasing functions were used, given that their variations are uniform. For health centers, early education, high school, and commerce, sigmoidal decreasing functions were used. According to Lima et al. [77], sigmoidal curves favor short distances over long distances.

\subsection{Cost-Distance Accessibility Index}

In this stage (represented by Phase I in Figure 1), an accessibility index map was developed for each LI in the model, where each roadway network point has an accessibility score in relation to LI. With the normalized distance-cost ratio and the weights for each LI, the accessibility index was calculated using Equations (1) and (2). In order to obtain global indices for each point, all group indices had to be determined, which enabled an isolated analysis by the type of urban facility. Equation (1) was used to arrive at the weighted sum of the distance-cost, along with the weight for each LI (Table 3). 
Next, Equation (2) was used to calculate the weighted sum of the indices for the three LI groups, using their weights; this resulted in a global accessibility map in vector form, which is presented in Figure 4a. Color variation from green to red was adopted for the study, with red corresponding to the least accessible areas and green corresponding to the most accessible. The results express a continuous variation in the accessibility index between 0 and 1, indicating, respectively, from zero to total accessibility. It was verified that many territorial locations do not have urban roadways and that there are no network nodes, in turn, diminishing accessibility. Greater values are found in the city's center, where more urban facilities are located.

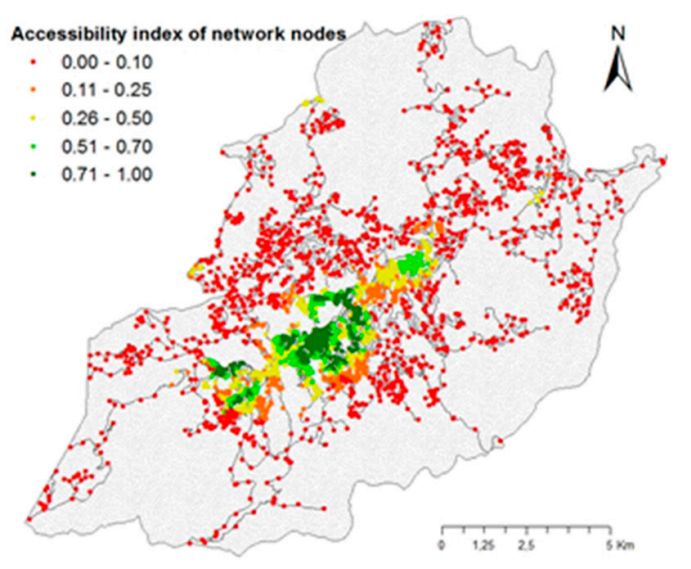

(a)

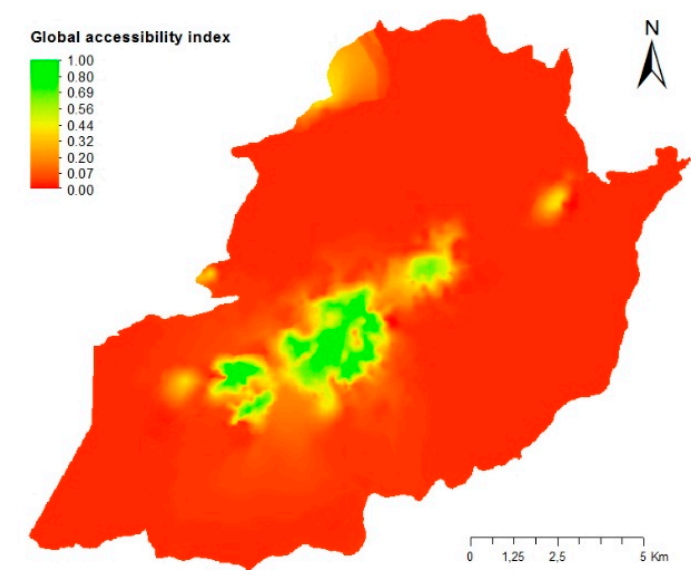

(b)

Figure 4. Accessibility index using distance-cost. (a) Global Accessibility index of network nodes; (b) Global Accessibility I.

Based on the vector format (and distance-cost), raster accessibility maps were developed and are presented in Figure $4 \mathrm{~b}$. This procedure was carried out by interpolating the index values using the kriging tool in GIS, formed by a continuous surface of the area under study.

The areas farthest away from highways demonstrated the lowest values-zero in some cases-as they are located within the roadway network and are distant from LI. The areas of greatest accessibility are concentrated along the outline of the main roadway, as seen in Figure 3c, where the majority of public facilities are located.

\subsection{Accessibility Index with Friction Factors}

The region under study has a relatively heterogeneous topography. In order to consider these characteristics, the second phase of this study (seen in Figure 1) incorporated other relevant aspects of the analysis (flexibility is one of the advantages of multicriteria accessibility method). The types of pavement and slope were considered as friction measured to determine the difficulties of mobility. Paved roads provide greater ease of mobility, making it possible to travel at greater velocities in motorized vehicles and on bicycles. This is also true for pedestrians who are able to walk more safely on roadways which have sidewalks. On the other hand, non-paved roads make trips more difficult. The road system of Campos do Jordão has a total of $622,218 \mathrm{~m}$ of urban roads, and 322,807 $\mathrm{m}$ are unpaved. This corresponds to more than $52 \%$ of the total. In the region under study, problems with drainage, holes, erosion, and construction collapse are a constant during rainy periods, which result in more challenges for urban travel. Therefore, Figure $3 \mathrm{~d}$ was converted into raster format to classify the normalized values from 0.50 for non-paved roadways, 1.00 for paved roadways, and 0.00 for regions which do not possess any roadways.

Road declivity is a factor which interferes in mobility for both pedestrians, cyclists, and drivers, given that the greater the slope, the more effort that is required. IPT [91] presents values from $1 \%$ to $15 \%$ for the maximum tolerable inclination for circulating vehicles. The city land is predominantly 
hilly, with slopes between of $20 \%$ to $45 \%$. Values above $45 \%$ were reclassified as 0 (fuzzy function control point), given that slopes above $50 \%$ are not recommended for urbanization. The reclassified maps for pavement and slopes served as a basis for spatial analysis which generated the friction map, according to Figure 5.

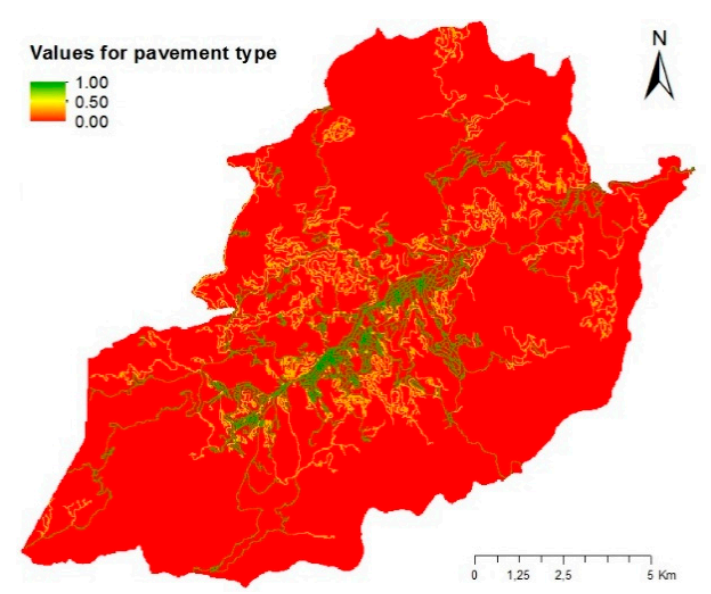

(a)

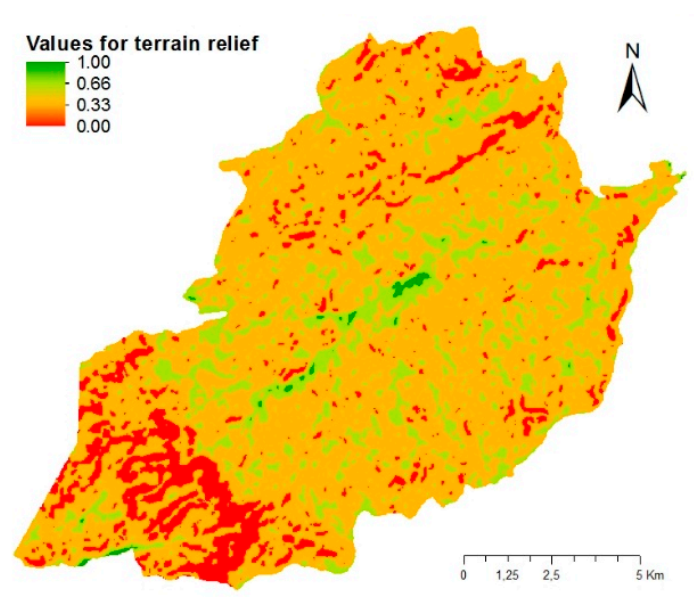

(b)

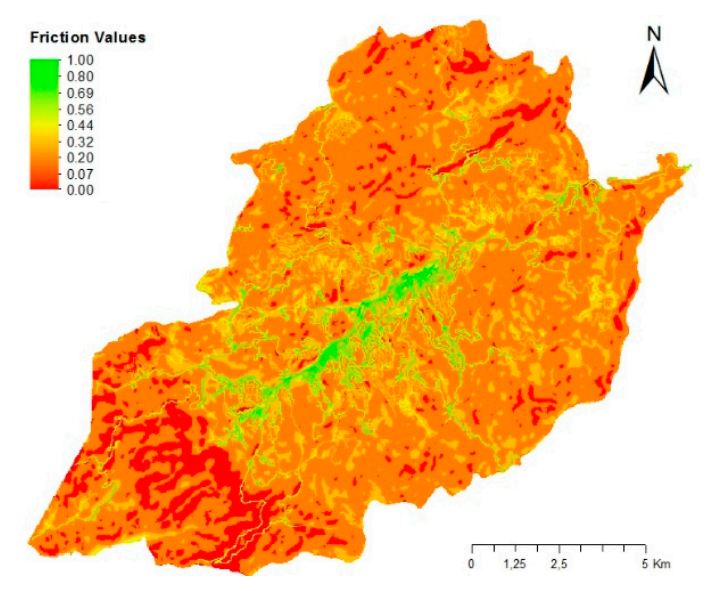

(c)

Figure 5. Friction factors for the accessibility: (a) Types of pavement; (b) declivity; and (c) normalized friction.

Continuing the evaluation, the spatial analysis calculated the weighted sum for the friction maps (Figure $5 c$ ) with the accessibility indices for distance-cost (Figure $4 a$ ), considering $60 \%$ of the initially calculated index and $40 \%$ of the friction values. This calculation and overlap generated new accessibility indices. As seen in Phase I, in Phase II (Figure 1), each LI's accessibility index was determined and a combination of these indices generated a final territorial accessibility map. Therefore, the combination (weighted sum) of the accessibility indexes of each LI group along with the friction values (map of the Figure 5c) generated accessibility maps per LI for "Education Facilities"; "Health Facilities", and "Services and Goods Facilities". These are all presented in Figure 6a-c, respectively. 


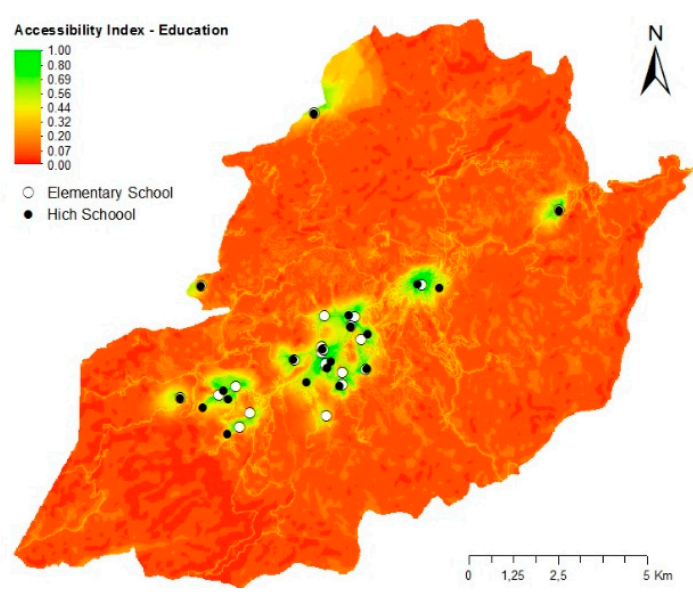

(a)

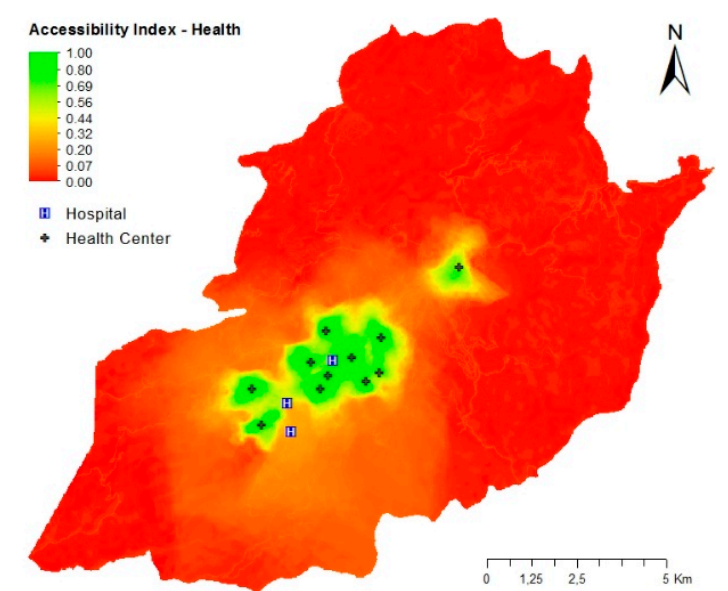

(b)

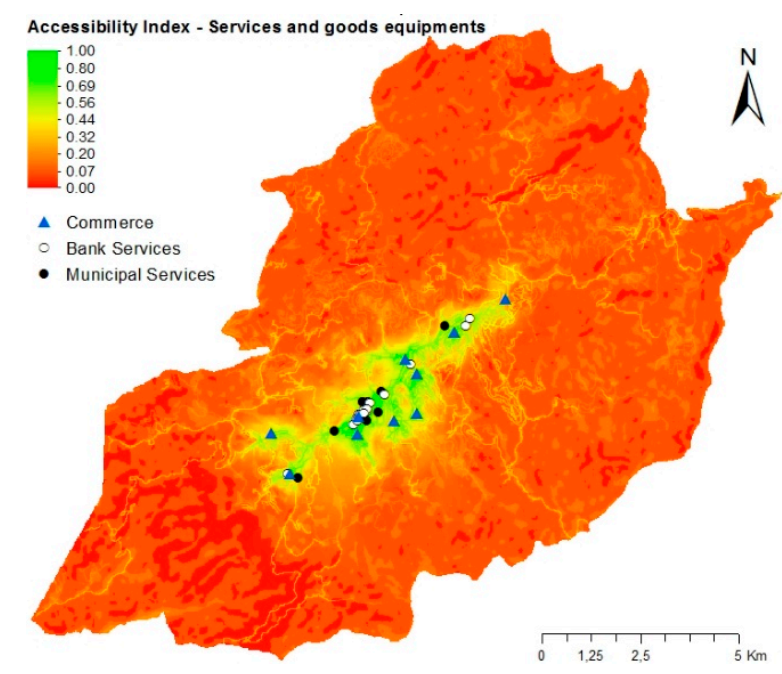

(c)

Figure 6. Accessibility per LI group: (a) Education; (b) health; and (c) services and goods.

When declivity and pavement type were incorporated in the analyses as friction while traveling (Figure 5), the results were more representative of the real accessibility conditions in the location of interest. Differences are observed in the values of the indices for the three LI groups (Figure 6a-c). The location of each type of urban facility defines these variances. Hospitals, health centers, banking, and other services are gathered in the central region and around the main avenue, leading to a greater concentration of more accessible areas (Figure 6b,c). Looking at the education group (Figure 6a), there are municipal schools located outside the central region in outlying neighborhoods, which brought about improvement in accessibility to education facilities in these more distant reaches of the city's roadway network.

Figure 7 presents the final map-Global Accessibility II. In general, areas which have thoroughfares had greater overall index scores (around 0.5). This tendency increased even more when the roadways are paved (around 0.7 ). Thus, the results showed that locations with greater accessibility were along paved thoroughfares and in areas near downtown that have less declivity. The worst indices were seen in areas with high levels of declivity ( $45 \%$ and above) in regions far from the downtown area and distant from urban thoroughfares. 


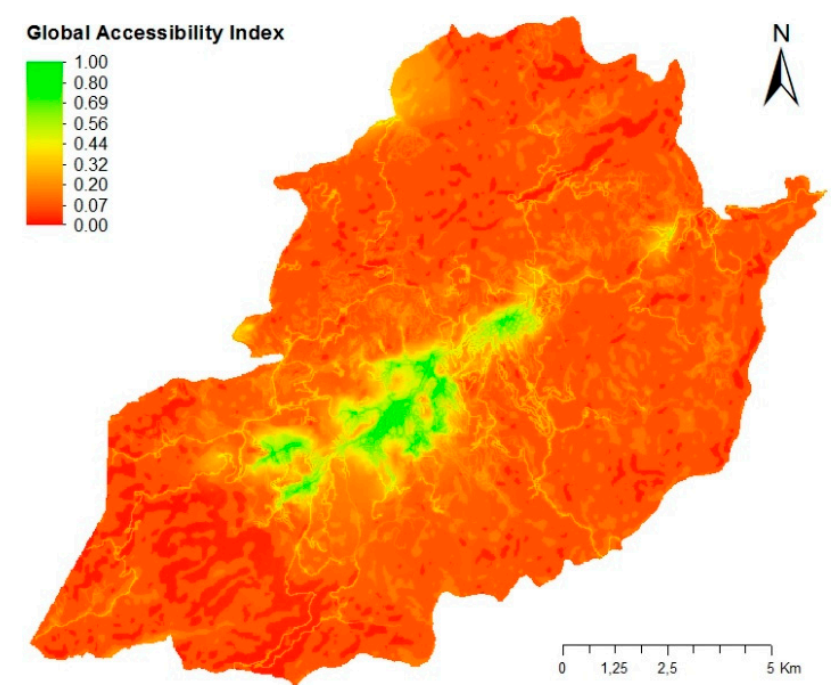

Figure 7. Global Accessibility II.

The incorporation of friction factors enabled the generation of maps which represent accessibility conditions in a more accurate way. According to a statistical analysis, when comparing evaluation without friction factors and with friction factors, a small variation in the mean value of the accessibility index (from 0.394 to 0.419 ) occurred in the area up to two kilometers around the main road axis. In the remaining region, there was a variation of approximately $10 \%$ in mean value of the accessibility index (for example, in the more distant areas, the index increased from 0.017 to 0.134 , since it was considered the existence of roads and declivity), indicating the importance of considering friction factors in accessibility assessment.

\section{Discussion and Conclusions}

Our study presented a nontraditional approach with the use Fuzzy Multicriteria Analysis Method integrated to spatial analysis. The accessibility was evaluated according to a purpose, and each destination has a different importance. The use of different importance factors was an interesting approach for accessibility which evaluated and weighted the different urban facility locations. As a result, in the opinion of the stakeholders, accessibility is the measurement which expresses the greatest intensity and ease of access to education (greatest weight), followed by health and by services and goods facilities. In Brazil, contrary to most developed countries, many trips to school are carried out in privately-owned vehicles; that is, parents take their children to school because the government does not provide collective transportation. This factor may have influenced the opinion of the stakeholders. However, as the model is quite flexible, the importance weights attributed to the LI can be adapted when applied to other countries with different travel characteristics than those found in Brazil. There is not an ideal number of stakeholders to define the degree of importance of destinations (our model's criteria). This number can be extended in a future work to contribute further with the results. We still can consider the population opinion with a larger sampling.

Another interesting result is related to the Brainstorming Method, which proved to be a useful tool in aiding in the definition of urban facilities and their level of importance in the accessibility assessment. The results for this application corroborate the results presented in the literature: It is an easy-to-understand tool which aided in the construction of ideas and opinions [83-85] and still enabled the intermediation of the researcher during the entire process, contributing to a greater understanding of the work proposal and a consensus of judgements from different stakeholders. Through brainstorming, the study also addressed the maximum distances which urban facilities should dispersed geographically in relation one's residence in order to remain accessible. In doing so, this 
complements the discussion of the importance of proximity to residential areas in relation to urban facilities $[17,92]$ and aligns with city planning to ease the daily activities of the population [3].

The analysis was developed based on the territorial accessibility index of the urban facilities in two stages: The first considered the distance-cost metrics, and the second incorporated friction factors (territorial declivity and the presence of roadways, paved or otherwise). Distance-costs measures were important for the process since it is a measurement of distance between the points. This generated a map based on accessibility for the second phase of development and analysis. However, this metric does not effectively represent the accessibility conditions between two points. On the other hand, the incorporation of friction factors enabled the generation of maps, which represented accessibility conditions in a more accurate way.

Adding friction analysis to these spatial index scores determined a new accessibility index which took into consideration a new group of aspects which interfere with the trip, providing a more representative portrait of the real accessibility conditions in urban facilities. There was improvement in the index values in areas near the roadway network, mainly on paved roadways with a low declivity. High declivity and the absence of roadways led to lower index scores, since these places are not as accessible and, in some cases, inadequate for urban occupation.

Spatial analysis was carried out using GIS and conducted in the Brazilian municipality of Campos do Jordão in the state of São Paulo. The use of ArcGIS software enabled the integration of a multicriteria method in an efficient manner, making it possible to represent spatial factors in the analysis, both mathematically and visually. The case study presented some limitations due to data availability. The accessibility evaluation model which considers distance-cost measures and friction factors can be more in-depth by considering other socioeconomic and transportation characteristics, such as questions related to the location of businesses, transportation modes, and public transportation demand. However, even without considering these additional attributes, the result of the model application, when compared to on-site observation, demonstrated coherence with the city's actual situation. For example, the greatest accessibility indices were seen along the municipality's main road axis, which contains the most LI, with paved roads and a low declivity. These places have greater resident population concentration and, in turn, greater demand for public transportation, while also presenting better transport infrastructure, with bicycle paths and sidewalks in good conditions of service.

Finally, the model's application in case-study form offered great contribution to the studied region in Southeastern Brazil, and the results have some policy implications in terms of (i) urban planning, (ii) city form, and (iii) sustainable urban mobility. The study converges on the approach of intelligent cities $[17,93,94]$, in which one of the concepts is making areas of daily activities closer to areas where a city's population resides. The results have shown that special attention should be paid to the planning of new school facilities as well as to the city's transportation system (paved highways and public transportation). Most of these services are currently concentrated in the city's central region, making access to urban facilities inefficient and unfair, especially in remote areas where most tourists reside and where many people work.

This approach also aligns with Lynch's Performance Dimension [3] since Campos do Jordão demonstrates characteristics of fragmentation and dispersion between contemporary cities. Seeking sustainable urban mobility and quality of urban space, cities must create possibilities to access activities, services, places, and information. The proposed model allowed us to generate scenarios and to point out the critical locations in relation to these issues, proving to be an important tool to aid decision-making without disregarding the needs of the people who make up that environment.

The context presented in the accessibility evaluation is interdisciplinary, and furthering this analysis in the implementation of urban projects, mainly related to allocation (or re-allocation) of future urban facilities, also contributes to the reduction of individual motorized transportation as well as the daily activities of the population. The scientific and social relevance of this article is to jointly analyze spatial and social segregation and accessibility in medium-sized cities. Accessibility issues 
and spatial segregation studied together have an epistemological deficiency. In addition, there is a gap in research on medium-sized cities. What we usually see are studies in larger cities, which have different dynamics for urban growth and daily trips. Furthermore, it is understood that the study had an important contribution to a realization of the distribution, distinction, and urban configuration of the different social groups in the urban area of the municipality of Campos do Jordão.

The result identified impaired accessibility locations and areas with social and spatial segregation. Thus, this paper contributed information so that the government may adopt measures targeting housing, location of public facilities, road systems, and public transportation issues.

Author Contributions: The authors confirm contribution to the paper as follows: Conceptualization, J.d.C.A. and C.M.S.; Formal analysis, J.d.C.A.; Investigation, J.d.C.A.; Methodology, J.P.L.; Software, J.d.C.A. and N.A.D.P.; Supervision, J.P.L. and N.A.D.P.; Writing—original draft, J.P.L., J.d.C.A. and N.A.D.P.; Writing-review \& editing, C.M.S. All authors reviewed the results and approved the final version of the manuscript.

Funding: This research received no external funding.

Acknowledgments: The authors would like to express their gratitude to the Brazilian agencies CNPq (National Council for Scientific and Technological Development), FAPEMIG (Foundation for the Promotion of Science of the State of Minas Gerais) and CAPES (Coordination of Superior Level Staff Improvement in Brazil), which have been supporting the efforts for the development of this work in different ways and periods.

Conflicts of Interest: The authors declare no conflict of interest.

\section{References}

1. Levinson, D.M. Accessibility and the journey to work. J. Transp. Geogr. 1998, 6, 11-21. [CrossRef]

2. Cascetta, E.; Cartenì, A.; Montanino, M. A new measure of accessibility based on perceived opportunities. Procedia-Soc. Behav. Sci. 2013, 87, 117-132. [CrossRef]

3. Lynch, K. A Theory of Good City Form; MIT Press: Cambridge, MA, USA, 1981.

4. Geurs, K.T.; Wee, B.V. Accessibility evaluation of land-use and transport strategies: Review and research directions. J. Transp. Geogr. 2004, 12, 127-140. [CrossRef]

5. Litman, T. Active Transportation Policy Issues; Victoria Transport Policy Institute: Victoria, BC, Canadá, 2014; Available online: http:www.vtpi.org (accessed on 8 July 2018).

6. Murawskia, L.; Church, R.L. Improving accessibility to rural health services: The maximal covering network improvement problem. Socio-Econ. Plan. Sci. 2009, 43, 102-110. [CrossRef]

7. Páez, A.; Scott, D.M.; Morency, C. Measuring accessibility: Positive and normative implementations of various accessibility indicators. J. Transp. Geogr. 2012, 25, 141-153. [CrossRef]

8. Foti, F.; Waddell, P. Modeling WalkTrips Using a Multi-Modal Accessibility Framework. In Proceedings of the Transportation Research Board 93rd Annual Meeting, Washington, DC, USA, 12-16 January 2014; Available online: https://trid.trb.org/view.aspx?id=1289226 (accessed on 1 December 2019).

9. Campbell, K.B.; Rising, J.A.; Klopp, J.M.; Mbilo, J.M. Accessibility across transport modes and residential developments in Nairobi. J. Transp. Geogr. 2019, 74, 77-90. [CrossRef]

10. Chou, T.Y.; Hsu, C.L.; Chen, M.C. A fuzzy multi-criteria decision model for international tourist hotels location selection. Int. J. Hosp. Manag. 2008, 27, 293-301. [CrossRef]

11. Bocarejo, S.J.P.; Oviedo, H.D.R. Transport accessibility and social inequities: A tool for identification of mobility needs and evaluation of transport investments. J. Transp. Geogr. 2012, 24, 142-154. [CrossRef]

12. Sun, B.; Zhou, H.Z.; Zhang, T.; Wang, R. Urban spatial structure and commute duration: An empirical study of China. Int. J. Transp. 2016, 10, 638-644. [CrossRef]

13. Allen, W.; Liu, D.; Singer, S. Accessibillity measures of U.S. Metropolitan areas. Transp. Res. Part B Methodol. 1993, 27, 439-450. [CrossRef]

14. Handy, S.L.; Niemeier, D.A. Measuring accessibility: An exploration of issues and alternatives. Environ. Plan. A 1997, 29, 1175-1194. [CrossRef]

15. Cheng, G.; Zeng, X.; Duan, L.; Lu, X.; Sun, H.; Jiang, T.; Yuli, L.Y. Spatial difference analysis for accessibility to high level hospitals based on travel time in Shenzhen, China. Habitat Int. 2016, 53, 485-494. [CrossRef]

16. Farber, S.; Fub, L. Dynamic public transit accessibility using travel time cubes: Comparing the effects of infrastructure (dis)investments over time. Comput. Environ. Urban Syst. 2017, 62, 30-40. [CrossRef] 
17. Rodrigues, D.S.; Mendes, J.F.G.; Lima, J.P.; Ramos, R.A.R. A Multicriteria Approach to Accessibility Assessment. In Contributions to Sustainable Development in Portuguese and Brazilian Cities, 1st ed.; Mendes, J.F.G., Silva, A.N.R., Souza, L.C.L., Ramos, R.A.R., Eds.; Coimbra, Portugal: Almedina, Coimbra, 2004; Volume 1, pp. 98-117.

18. Chaloux, N.; Boisjoly, G.; Grise, E.; El-Geneidy, A.; Levinson, D. I Only Some Satisfaction: Introducing Satisfaction Measures of Accessibility. Trans. Res. Part F Traffic Psychol. Behav. 2018, 62, 833-843.

19. Banai, R.; Rapino, M.A. Urban theory since A Theory of Good City Form 1981-A progress review. J. Urban. 2009, 2, 259-276.

20. Levinson, D.M.; Marshall, W.; Axhausen, K. Elements of Access: Transport Planning for Engineers, Transport Engineering for Planners; Network Design Lab: Sydney, Australia, 2017.

21. Geurs, K. Transport Planning with Accessibility Indices in the Netherlands; International Transport Forum Discussion Papers, No. 2018/09; OECD Publishing: Paris, France, 2018. [CrossRef]

22. Wang, Y.; Chen, B.Y.; Yuan, H.; Wang, D.; Lam, W.H.; Li, Q. Measuring temporal variation of location-based accessibility using space-time utility perspective. J. Transp. Geogr. 2018, 73, 13-24. [CrossRef]

23. Wilson, A.G. Land-use/transport Interaction Models: Past and Future. J. Transp. Econ. Policy 1998, 32, 3-26.

24. Badoe, D.A.; Miller, E.J. Transportation-land-use interaction: Empirical findings in North America, and their implications for modeling. Transp. Res. Part D Transp. Environ. 2000, 5, 235-263. [CrossRef]

25. Shaw, S.L.; Xin, X. Integrated land use and transportation interaction: A temporal GIS exploratory data analysis approach. J. Transp. Geogr. 2003, 11, 103-115. [CrossRef]

26. Renne, J.L. Transportation and land development: A global view. Res. Transp. Econ. 2016, 60, 1-2. [CrossRef]

27. Mayaud, J.R.; Tran, M.; Pereira, R.H.; Nuttall, R. Future access to essential services in a growing smart city: The case of Surrey, British Columbia. Comput. Environ. Urban Syst. 2019, 73, 1-15. [CrossRef]

28. Bowman, J.L.; Ben-Akiva, M.E. Activity-based disaggregate travel demand model system with activity schedules. Transp. Res. Part A Policy Pract. 2001, 35, 1-28. [CrossRef]

29. Gärling, T.; Schuitema, G. Travel Demand Management Targeting Reduced Private Car Use: Effectiveness, Public Acceptability and Political Feasibility. J. Soc. Issues 2007, 63, 139-153. [CrossRef]

30. Metz, D. Demographic determinants of daily travel demand. Transp. Policy 2012, 21, 20-25. [CrossRef]

31. Ghasri, M.; Rashidi, T.H.; Waller, S.T. Developing a disaggregate travel demand system of models using data mining techniques. Transp. Res. Part A Policy Pract. 2017, 105, 138-153. [CrossRef]

32. Niehausa, M.; Galilea, P.; Hurtubi, R. Accessibility and equity: An approach for wider transport project assessment in Chile. Res. Transp. Econ. 2016, 59, 412-422. [CrossRef]

33. Beiler, O.M.; Mohammed, B.M. Exploring transportation equity: Development and application of a transportation justice framework. Transp. Res. Part D Transp. Environ. 2016, 47, 285-298. [CrossRef]

34. Taleai, M.; Sliuzas, R.; Flacke, J. An integrated framework to evaluate the equity of urban public facilities using spatial multi-criteria analysis. Cities 2014, 40, 56-69. [CrossRef]

35. Zhang, T.; Zeng, Z.; Jia, T.; Lie, J. Examining the amenability of urban street networks for locating facilities. Phys. A Stat. Mech. Appl. 2016, 457, 469-479. [CrossRef]

36. Li, R.; Tong, D. Incorporating activity space and trip chaining into facility siting for accessibility maximization. Socio-Econ. Plan. Sci. 2017, 60, 1-14. [CrossRef]

37. Bedoya, V.R.; Miralles-Guasch, C. Local accessibility inequalities and willingness to walk in Latin-American cities: Findings from Medellín, Colombia. Int. J. Sustain. Transp. 2017, 11, 186-196. [CrossRef]

38. Jeong, J.S.; Ramírez-Gómez, Á. Optimizing the location of a biomass plant with a fuzzy-Decision-Making Trial and Evaluation Laboratory (F-DEMATEL) and multi-criteria spatial decision assessment for renewable energy management and long-term sustainability. J. Clean. Prod. 2018, 182, 509-520. [CrossRef]

39. Malczewski, J.; Jackson, M. Multicriteria spatial allocation of educational resources: An overview. Socio-Econ. Plan. Sci. 2004, 34, 219-235. [CrossRef]

40. Feizizadeh, B.; Blaschke, T.; Nazmfar, H.; Rezaei Moghaddam, M.H. Landslide susceptibility mapping for the Urmia Lake basin, Iran: A multi-criteria evaluation approach using GIS. Int. J. Environ. Res. 2013, 7, 319-336.

41. Malczewski, J. GIS-based multicriteria decision analysis: A survey of literature. Int. J. Geogr. Inf. Sci. 2006, 20, 703-726. [CrossRef] 
42. Câmara, G.D.C.; Monteiro, A.M.V. Introduction to the Science of Geoinformation; National Institute of Space Research (INPE): São José dos Campos, Brazil, 2001; Available online: http://mtc-m12.sid.inpe.br/col/sid. inpe.br/sergio/2004/04.22.07.43/doc/publicacao.pdf (accessed on 12 November 2018).

43. Chang, N.B.; Parvathinathan, G.; Breeden, J.B. Combining GIS with fuzzy multicriteria decision-making for landfill siting in a fast-growing urban region. J. Environ. Manag. 2008, 87, 139-153. [CrossRef] [PubMed]

44. Malczewski, J. Ordered weighted averaging with fuzzy quantifiers: GIS-based multicriteria evaluation for land-use suitability analysis. Int. J. Appl. Earth Obs. Geoinf. 2006, 8, 270-277. [CrossRef]

45. Mustafa, A.A.; Singh, M.; Sahoo, R.N.; Ahmed, N.; Khanna, M.; Sarangi, A.; Mishra, A.K. Land suitability analysis for different crops: A multi criteria decision making approach using remote sensing and GIS. Researcher 2011, 3, 61-84.

46. Phua, M.H.; Minowa, M. A GIS-based multi-criteria decision making approach to forest conservation planning at a landscape scale: A case study in the Kinabalu Area, Sabah, Malaysia. Landsc. Urban Plan. 2005, 71, 207-222. [CrossRef]

47. Joerin, F.; Thériault, M.; Musy, A. Using GIS and outranking multicriteria analysis for land-use suitability assessment. Int. J. Geogr. Inf. Sci. 2001, 15, 153-174. [CrossRef]

48. Saghapour, T.; Moridpour, S.; Thompson, R.G. Public transport accessibility in metropolitan areas: A new approach incorporating population density. J. Transp. Geogr. 2016, 54, 273-285. [CrossRef]

49. Mendes, J.F.; Rodrigues, D.S.; Ramos, R.A. A GIS-based multicriteria model for the evaluation of territorial accessibility. WIT Trans. Ecol. Environ. 2005, 84, 805-813.

50. Meng, Y.; Malczewski, J.; Boroushaki, S. A GIS-based multicriteria decision analysis approach for mapping accessibility patterns of housing development sites: A case study in Canmore, Alberta. J. Geogr. Inf. Syst. 2011, 3, 50. [CrossRef]

51. Feng, T.; Zhang, J. Multicriteria evaluation on accessibility-based transportation equity in road network design problem. J. Adv. Transp. 2014, 48, 526-541. [CrossRef]

52. Zhu, X.; Liu, S.; Yeow, M.C. Accessibility analysis for housing development in Singapore with GIS and multi-criteria analysis methods. Appl. Gis 2006, 2, 13-1. [CrossRef]

53. Agbenyo, F.; Nunbogua, A.M.; Dongzagla, A. Accessibility mapping of health facilities in rural Ghana. J. Transp. Health 2017, 6, 73-83. [CrossRef]

54. Kahraman, C.; Cebeci, U.; Ulukan, Z. Multi-criteria supplier selection using fuzzy AHP. Logist. Inf. Manag. 2003, 16, 382-394. [CrossRef]

55. Mendes, J.F.G. Multicriteria accessibility evaluation using GIS as Applied to Industrial Location in Portugal. Earth Obs. Mag. 2001, 10, 31-35.

56. Sakamoto, E.; Lima, J.P. Accessibility in the rural environment: A multicriteria approach using GIS. Transportation 2016, 24, 63-73. [CrossRef]

57. Dragićević, S.; Lai, T.; Balram, S. GIS-based multicriteria evaluation with multiscale analysis to characterize urban landslide susceptibility in data-scarce environments. Habitat Int. 2015, 45, 114-125. [CrossRef]

58. Jelokhani-Niaraki, M.; Malczewski, J. Decision complexity and consensus in Web-based spatial decision making: A case study of site selection problem using GIS and multicriteria analysis. Cities 2015, 45, 60-70. [CrossRef]

59. Veronesi, F.; Schito, J.; Grassi, S.; Raubal, M. Automatic selection of weights for GIS-based multicriteria decision analysis: Site selection of transmission towers as a case study. Appl. Geogr. 2017, 83, 78-85. [CrossRef]

60. Vahdat, K.; Smith, N.J.; Amiri, G.G. Fuzzy multicriteria for developing a risk management system in seismically prone areas. Socio-Econ. Plan. Sci. 2014, 48, 235-248. [CrossRef]

61. Wang, H.; Duanmu, L.; Lahdelma, R.; Li, X. A fuzzy-grey multicriteria decision making model for district heating system. Appl. Therm. Eng. 2018, 128, 1051-1061. [CrossRef]

62. Hu, A.; Zhang, L.; Chen, D.; Pedrycz, W.; Yu, D. Gaussian kernel based fuzzy rough sets: Model, uncertainty measures and applications. Int. J. Approx. Reason. 2010, 51, 453-471. [CrossRef]

63. Machado, M.H.; Lima, J.P. Multicriteria evaluation of people with reduced mobility accessibility: A study in downtown Itajubá (MG). Urbe. Braz. J. Urban Manag. 2015, 7, 368-382. [CrossRef]

64. Hawas, Y.E.; Hassan, M.N.; Abulibdeh, A. A multi-criteria approach of assessing public transport accessibility at a strategic level. J. Transp. Geogr. 2016, 57, 19-34. [CrossRef] 
65. Aydin, S.; Kahraman, C.; Kaya, I. A new fuzzy multicriteria decision making approach: An application for European Quality Award assessment. Knowl.-Based Syst. 2012, 32, 37-46. [CrossRef]

66. Engau, A.; Moffattm, C.; Dyk, W. Multicriteria modeling and tradeoff analysis for oil load dispatch and hauling operations at Noble energy. Optim. Eng. 2015, 16, 73-101. [CrossRef]

67. Banai, R. Public Transportation Decision-Making: A Case Analysis of the Memphis Light Rail Corridor and Route Selection with Analytic Hierarchy Process. J. Public Transp. 2006, 9, 1-24. [CrossRef]

68. Saaty, T.L. Decision making with the analytic hierarchy process. Int. J. Serv. Sci. 2008, 1, 83-98. [CrossRef]

69. Banai, R. Evaluation of land use-transportation systems with the Analytic Network Process. J. Transp. Land Use. 2010, 3, 85-112. [CrossRef]

70. Saaty, T.L. Fundamentals of the analytic network process. J. Syst. Sci. Syst. Eng. 2004, 13, 129-157. [CrossRef]

71. Michailidou, A.V.; Vlachokostas, C.; Moussiopoulos, N. Interactions between climate change and the tourism sector: Multiple-criteria decision analysis to assess mitigation and adaptation options in tourism areas. Tourism Manag. 2016, 55, 1-12. [CrossRef]

72. Jeong, J.S.; García-Moruno, L.; Hernández-Blanco, J. Alonso Sánchez-Ríos, Planning of rural housings in reservoir areas under (mass) tourism based on a fuzzy DEMATEL-GIS/MCDA hybrid and participatory method for Alange, Spain. Habitat Int. 2016, 57, 143-153. [CrossRef]

73. Tavares, G.; Zsigraiová, Z.; Semiao, V. Multi-criteria GIS-based siting of an incineration plant for municipal solid waste. Waste Manag. 2011, 31, 1960-1972. [CrossRef]

74. Hariz, H.A.; Dönmez, C.C.; Sennaroglu, B. Siting of a central healthcare waste incinerator using GIS-based Multi-Criteria Decision Analysis. J. Clean. Prod. 2017, 166, 1031-1042. [CrossRef]

75. Akıncı, H.; Özalp, A.Y.; Turgut, B. Agricultural land use suitability analysis using GIS and AHP technique. Comput. Electron. Agric. 2013, 97, 71-82. [CrossRef]

76. Zolekar, R.B.; Bhagat, V.S. Multi-criteria land suitability analysis for agriculture in hilly zone: Remote sensing and GIS approach. Comput. Electron. Agric. 2015, 118, 300-321. [CrossRef]

77. Tobias, M.S.G.; Ramos Rui, A.R.; Rodrigues, D.S. Spatial Analysis of Accessibility to Support Decision-Making in Urban Investments: A case in Amazonia-Brazil. In Proceedings of the 13th WCTR-World Conference Transport Research, Rio de Janeiro, Brazil, 15-18 July 2013; pp. 1-10.

78. Lima, J.P.; Ramos, R.A.R.; Fernandes Júnior, J.L. A multicriteria approach to the prioritization of paved roads. Transportes 2009, 17, 27-38. [CrossRef]

79. Yang, J.; Yang, y.; Chen, R.S.; Meng, X.Z.; Xu, J.; Qadeer, A.; Liu, M. Modeling and evaluating spatial variation of polycyclic aromatic hydrocarbons in urban lake surface sediments in Shanghai. Environ. Pollut. 2018, 235, 1-10. [CrossRef]

80. Lima, J.P.; Machado, M.H. Walking accessibility for individuals with reduced mobility: A brazilian case study. Case Stud. Transp. Policy 2019. [CrossRef]

81. Stillwell, W.G.; Seaver, D.A.; Edwards, W. A Comparison of Weight Approximation Techniques in Multiattribute Utility Decision-Making. Org. Behav. Hum. Perform. 1981, 28, 62-77. [CrossRef]

82. Banai, R.; Wakolbingerb, T. A measure of regional influence with the analytic network process. Socio-Econ. Plan. Sci. 2011, 45, 165-173. [CrossRef]

83. Hicks, M.J. Problem Solving and Decision Making: Hard, Soft and Creative Approaches; Cengage Learn: Stamford, CT, USA, 2004.

84. Osborn, A.F. Applied Imagination; Oxford: England, UK, 1953.

85. Kohn, N.H.; Paulus, P.B.; Choi, Y. Building on the ideas of others: An examination of the idea combination process. J. Exp. Soc. Psychol. 2011, 47, 554-561. [CrossRef]

86. Paulus, P.B.; Brown, V.R. Toward more creative and innovative group idea generation: A cognitive-social-motivational perspective of brainstorming. Soc. Personal. Psychol. Compass 2007, 1, 248-265. [CrossRef]

87. Rietzschel, E.F.; Nijstad, B.; Stroebe, W. Productivity is not enough: A comparison of interactive and nominal brainstorming groups on idea generation and selection. J. Exp. Soc. Psychol. 2006, 42, 244-251. [CrossRef]

88. Clark, I.L. Concepts in Composition: Theory and Practice in the Teaching of Writing, 2rd ed.; Routledge: New York, NY, USA, 2012.

89. IBGE Brazilian Institute of Geography and Statistics 2010 Cities. Available online: http://cod.ibge.gov.br/2AJ (accessed on 20 September 2018). 
90. Peuré-Tartaruga, L.A.; Gomeñuka, N.A. Walk Biomechanics on Slopes. Tecnicouro 2010, 4, 76-84.

91. IPT. Slopes Occupation Manual; Institute of Technological Research: São Paulo, Brazil, 1991; p. 216.

92. Newman, P.; Kenworthy, J. Urban Design to Reduce Automobile Dependence. Opolis 2006, 2, 35-52.

93. Albino, V.; Berardi, U.; Dangelico, R.M. Smart Cities: Definitions, Dimensions, Performance, and Initiatives. Int. J. Urban Technol. 2015, 22, 3-21. [CrossRef]

94. Haarstad, H. Constructing the sustainable city: Examining the role of sustainability in the 'smart city' discourse. Int. J. Environ. Policy Plan. 2016, 18, 1-15. [CrossRef]

(C) 2019 by the authors. Licensee MDPI, Basel, Switzerland. This article is an open access article distributed under the terms and conditions of the Creative Commons Attribution (CC BY) license (http://creativecommons.org/licenses/by/4.0/). 